\title{
Ranking EU Climate and Energy Policies
}

\author{
Ieva PAKERE ${ }^{1 *}$, Toms PRODANUKS ${ }^{2}$, Agris KAMENDERS ${ }^{3}$, Ivars VEIDENBERGS ${ }^{4}$, \\ Stefan HOLLER ${ }^{5}$, Agnese VILLERE $^{6}$, Dagnija BLUMBERGA ${ }^{7}$ \\ 1-4, 6,7 Riga Technical University, Azenes street 12/1, Riga, Latvia \\ ${ }^{5}$ HAWK Hildesheim/Holzminden/Göttingen University of Applied Sciences and Arts, \\ Rudolf-Diesel-Straße 12, 37075, Göttingen, Germany
}

\begin{abstract}
The European Union (EU) has set ambitious targets to increase the overall energy efficiency and decrease the environmental impact by introducing the 'Green Deal.' It is an EU plan for the transition to zero greenhouse gas emissions. The overall data analyses of GHG emissions per capita and GDP value in different EU countries show that the GDP increase in 2010-2017 has not increased GHG emissions. Therefore, the link between the GDP increase through energy resource usage increase has been eliminated. However, not all of the EU 27 member states contributed to the overall EU green policy equally. The article presents the methodology for the energy and environmental performance status analyses by evaluating nine different indicators (share of renewable energy, greenhouse gases per GDP, energy intensity, primary efficiency, industry efficiency, energy consumption in households, space heating efficiency, pollutant emissions from transport and specific energy consumption of transport sector) for $\mathrm{EU}$ member states. Indicators have been tested through correlation analyses. The use of multidimensional Energy and climate policy indicator has been proposed to rank the performance of different $E U$ countries. The results show that the countries with the highest score in climate and energy indicator values are Sweden, Denmark, Latvia, Austria, Finland, Ireland, and Lithuania. The lowest obtained values are Bulgaria, Poland, Hungary, the Czech Republic, and France.
\end{abstract}

Keywords - Energy indicators; environmental performance indicators; energy efficiency; climate policy evaluation

\section{INTRODUCTION}

During the last decades, a continuing shift from conventional to non-conventional sources of energy has been taking place. Due to the adverse environmental effects of conventional energy forms of production and usage, and the finite yields of conventional sources of energy, the need for renewable energy sources (RES) usage is becoming urgent [1].

Climate change and the impact of human economic activity have been a global issue for decades [1]. Since adopting the Kyoto Protocol in 2007, an environmentally friendly energy policy has been a critical frontrunner in climate action, including increased renewable energy resources (RES) in the energy sector and energy efficiency provision. Another step in greenhouse emission reduction besides the Kyoto Protocol adopted in 191 countries was establishing the Paris Agreement. The Paris Agreement that was ratified in 2016 agreed to reduce greenhouse gas emissions (GHG) by $80-90 \%$ by 2050 compared to 1990 . The European Union (EU) has also joined this agreement and set ambitious targets. The EU Renewable Energy Directive 2009/28/EC is stipulated that EU member states should achieve

\footnotetext{
* Corresponding author.

E-mail address: ieva.pakere@rtu.lv
} 
at least a $20 \%$ share of RES in the total energy consumption by the year 2020, but each EU member state could set its specific targets relating to each countries individual energy market and its development [2].

In December 2018, the new Renewable Energy Directive (2018/2001/EK) [3] entered into force, setting the EU member states a new binding renewable energy target of at least $32 \%$ by 2030 , including a clause for a possible upward revision by 2023 . In November 2018, the European Commission adopted a long-term strategic vision for a modern, competitive, and climate-neutral economy by 2050: 'A clean planet for all' [4]. The strategy puts energy at the heart of the transition to an emission-neutral economy because it accounts for more than $75 \%$ of the EU's greenhouse gas emissions. In all the scenarios analysed, the energy system is moving towards zero greenhouse gas emissions. The long-term strategy is based on a secure and sustainable energy supply based on a market and pan-European approach. The power system of the future will integrate electricity, gas, heating/cooling and mobility systems and markets through smart grids, and citizens will become the centre of the system. Considering that existing policies and strategic goals for 2030 can deliver only $60 \%$ GHG reductions in the long term, several scenarios for post-2030 policy change have been modelled. It has been concluded that opportunities such as RES (including biofuels), energy efficiency, the promotion of a circular economy, and individual transport solutions (electrification, hydrogen, alternative fuels, new mobility approaches) are insufficient to achieve zero emissions 2050 . These scenarios lead to only $80 \%$ emission reductions compared to 1990 levels, $90 \%$ when scenarios are combined. $\mathrm{CO}_{2}$ removals in agriculture and forestry are significant. However, this reduction is not sufficient. According previously mentioned, additional $\mathrm{CO}_{2}$ capture and storage options should be developed. [4].

Due to each EU member state's approach to the Green Deal and given the opportunity to choose each countries' criteria of $\mathrm{CO}_{2}$ reduction, significant risk can arise to fail to achieve the common objectives if individual EU member states do not take measures to mitigate climate change. Carbon-intensive goods imported from abroad can compete with locallyproduced carbon-based products. The EU economy would suffer if an effective Carbon Border Adjustment Mechanism has not been applied and effective and meaningful carbon pricing as part of a broader regulatory environment has not been set up [5].

\subsection{Integration of RES technologies for GHG emission reduction}

Countries included in the first Annex of the Kyoto Protocol have reduced their GHG emissions by an average of around one million tons of $\mathrm{CO}_{2}$ equivalent since 2005, gross domestic product (GDP) growth has been on average 1-2\% lower than non-member countries [6]. Due to the Paris Agreement and the EU instruments mentioned above, there is political pressure to develop the use of RES and related technologies, which have a positive economic impact. It is not clear how this effect will continue, with the world developing significantly in RES technology and energy efficiency [7]. Sustainable energy development depends on policy settings. Right-wing and populist political forces believe that measures to mitigate climate change and develop sustainable energy are only acceptable if they primarily benefit the country or are the sole beneficiary [8]. Therefore, evidence of the positive economic impact of sustainable energy provides support in the eyes of society and various political forces and ensures the implementation of climate change policies.

It has been argued if RES can influence GDP or vice versa. In some author studies, it has been stated that changes in GDP affect the consumption of RESs only for very high and very low-income countries [9]. The positive economic influence of RES on GDP has also been tested via statistical analysis, giving the view that a $1 \%$ increase in RES consumption can 
increase the total GDP by $0.105 \%$, while a $1 \%$ increase in the share of RESs in a country's energy mix can increase total GDP by $0.089 \%$

Authors believe that overall economic growth from how the energy sector develops is a common link and is nothing new and unusual [10]. It is gradually happening in many places, and the European Commission's long-term energy strategies have highlighted this trend shortly. But the unanswered question remains whether the increase in the share of RES in the total energy balance increase GDP and thus increase energy productivity, and does the share of the energy sector in GDP go hand in hand with energy productivity?

The authors point out that the use of RES has a positive impact on the sustainable development of the economy. For example, in a study on the impact of an accelerated transition to renewable energy on the global economy, Gielen et al. conclude that decision-makers and analysts underestimate the positive impact that the increased use of RES has on economic performance [11]. Papiež et al. [7] mark that research on the correlation between economic performance and GHG emissions focuses on four hypotheses: conservation, feedback, growth, and neutrality. According to the conservation hypothesis, GDP influences energy consumption. The feedback hypothesis assumes that energy consumption and GDP correlate, the growth hypothesis assumes that GDP growth has a significant impact on energy consumption, and the neutrality hypothesis assumes that there is no significant relationship between GDP and energy consumption. Although these hypotheses refer to energy consumption, they can also be applied to renewable RES consumption [12]. Most research on RES supports the economic growth hypothesis, showing that GDP growth is linked to increased RES use [7], [13].

However, some studies prove the opposite - the preservation hypothesis [14] and sources that favour feedback and neutrality hypothesis theories. While most scientists recognize that high GDP contributes to RES and sustainable policies in countries with high levels of prosperity, global sources have historically seen GDP growth because of GHG emissions. GDP growth is cited as one of the four major drivers behind GHG emissions (other forces include population growth, carbon-intensive economic activity, and energy intensity) [14].

Authors Liobikiene \& Butkus gathered data from 28 EU countries in 2017 and concluded that GDP increases by $0.05-0.06 \%$ as the share of RES in primary energy production increases by $1 \%$ [15]. Simionescu et al. [10] conducted an empirical analysis of the impact of GDP on the share of RES in electricity consumption based on EU data from 2007 to 2017. RES is considered to have a positive impact on economic growth by providing new jobs and technological innovation. Therefore, a causal relationship between the share of RES and GDP per capita was established. The data models indicated a positive but small impact of GDP on the share of RES in electricity generation. Therefore, it was concluded that further analysis of the impact of RES on environmental, economic, and social indicators is essential.

The main aim of this section was to provoke a discussion on the impact of RES on GDP formation and the different opinions of industry professionals on this issue. Despite different views on whether RES has an impact on GDP or whether GDP does affect the share of RES consumption, there is no clear answer to this question. However, the authors believe that sustainable environmental and energy sector development is possible directly by increasing the share of RES in the industry, which boosts economic growth, reduces final electricity tariffs for end-users, and reduces production costs and $\mathrm{CO}_{2}$ emissions.

\subsection{Indicators for energy and climate policies analyses}

Reaching sustainable development requires intelligent use of resources, technology, appropriate economic initiatives, and strategic policy planning at the local and national levels. Continuous monitoring of policy initiatives and strategies is also needed to see if they are 
approaching sustainable development. The use of energy indicators helps here. Indicators are the basis for discussing sustainable development issues with policymakers and the public. Several researches are analysing different indicators related to the performance of energy and environmental policies. The energy indicators developed by the International Atomic Energy Agency on Sustainable Development are examined under the three dimensions of sustainability - social, economic, and environmental - with 30 indicators [16].

Energy use, GDP per capita, and cost of fossil energy to GDP have been identified as the critical indicators for RES growth [16]. EU countries with low RES share are more self-sufficient in energy, such as Poland, the Czech Republic, Bulgaria, and Estonia, which have their coal or oil shale resources, and the Netherlands, Romania, and the United Kingdom have natural gas resources. In these cases, the transition to RES is likely to have a different impact on the national economy than for countries that already make extensive use of RES or abandon their purchased fossil energy resources to develop products and increase energy security [17]. Another study looks at GDP, foreign direct investment, energy efficiency, and renewable energy consumption on GHG emissions from 1990-2013. The study analysed 147 countries with different income levels and concluded that GDP growth contributes significantly to GHG emissions. This relation was particularly pronounced in middle-income countries. Exports were associated with decreasing GHG in high-income countries and increasing in low-income countries, while the impact of foreign investment on national GHG emissions is insignificant [18]. Authors Liobikiene \& Butkus have also modelled potential indirect effects to deepen the topic [19].

Other economic well-being indicators include the Sustainable Economic Well-being Index as a sustainability-oriented one [20]. Energy sustainability in the Baltic Sea Region countries has been studied using multi-criteria methods [21]. One of the indicators used in this study is primary energy consumption per unit of GDP. Interaction between GDP, GHG emissions, and RES share is explored in a study on green investments to GDP growth and GHG reduction [22]. The relationship between GDP and GHG growth and the potential for breaking this link has been studied in China [23]. The correlation between GDP, GHG emissions, and corruption in EU countries and Ukraine has also been studied in EU countries, and Ukraine and the Environmental Kuznets Curve hypothesis has been confirmed [24]. The link between economic performance and environmental aspects is also addressed in developing a regional economic model for Australia [25].

Although it has been assumed that GDP growth will almost certainly lead to increased GHG emissions, Baležentis et al. [26] argue that GDP growth can be decoupled from GHG growth and looks at bioenergy as the primary way to achieve it. The impact of social, economic, and environmental factors on sustainability in the EU has also been addressed in other sources [27], [28].

Report on GHG Emission Ratio to GDP in G7 countries (Canada, France, Germany, Italy, Japan, United Kingdom, and the United States) and BRIC countries (Brazil, Russia, India, and China) for 1990 to 2017 has been prepared by Zheng et al. [29]. Scientists from the USA study the economic impact of environmental policy and concludes that withdrawing from the Paris Agreement could increase GDP by about $1 \%$ in the medium term. However, the USA cannot achieve sustainable long-term development in the long term without additional incentives for green technologies and policies [30]. The link between emissions, energy consumption, and economic growth is also a significant issue in Gulf Cooperation Council countries [31] and Thailand [32].

The present research aims to conduct detailed analyses of EU member country-specific energy and climate performance in the EU from 2010-2017. The particular paper analyses emitted GHG emissions per capita and the level of GHG emissions emitted at the national 
level to assess the EU's progress in reducing GHG emissions in the energy sector. However, the authors point to a problem in the interpretation and application of available data, as neither emitted GHG nor share of RES in the energy sector clearly state precisely what is each EU member state long-term energy strategy and what kind of energy production capacities will be used in the future and whether new technologies will be implemented. The authors identify and test nine different indicators to evaluate the energy efficiency in different sectors, overall GHG emissions emitted, and the integration of RES in the energy sector to determine energy efficiency. Therefore, the methodology for determining the multidimensional Energy and Climate Policy index has been developed to rank the EU countries according to their energy sector performance.

\section{Methodology}

When selecting energy resources and related technologies for the production, supply, and use of energy services, it is essential to consider the economic, social, and environmental consequences. Policymakers need methods to measure and assess the current and future impact of energy consumption. The authors have developed the methodology for comparing climate and energy efficiency policies in different countries using nine different indicators. Therefore, the main steps of the particular research can be seen in Fig. 1. These include identifying different indicators for evaluation, overall statistical data analyses, and testing those indicators by applying correlation analyses. Further, the indicators are normalized and summed in order to determine ECPI index. It allows to group several countries with different policies and obtains insight into overall environmental and energy performance.

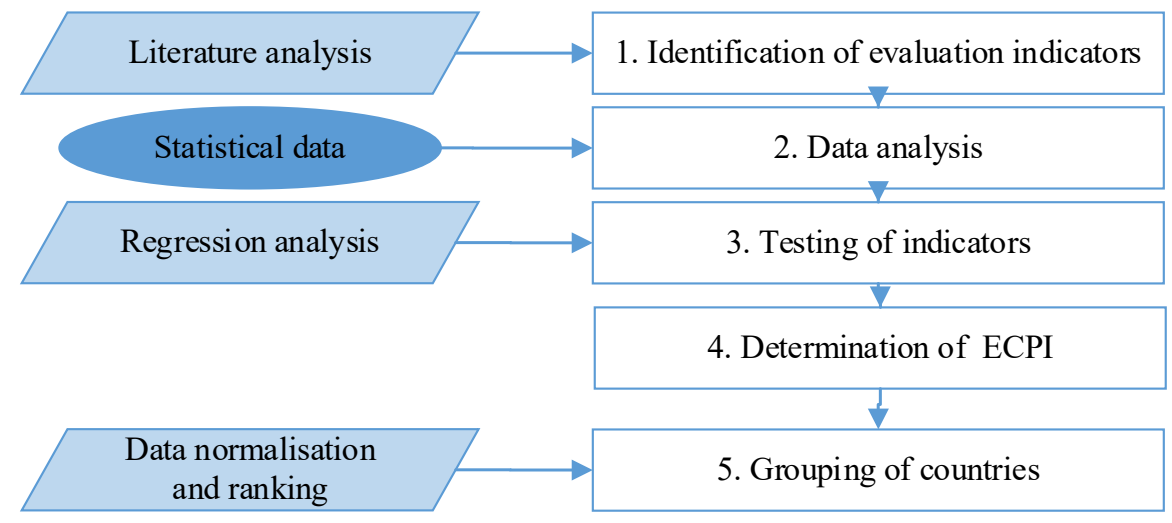

Fig. 1. Main steps of the research and used methods.

The used indicators are quantitative to provide a deeper understanding of the critical issues and highlight essential links that are not obvious to wider society regarding energy issues related to sustainable development. Each set of indicators in Fig. 1. illustrates aspects or consequences of energy production and its usage. Changes in the values of the indicator over time indicate progress or lack thereof towards sustainable development. Instead of relying on abstract analysis, policymakers have a simple set of numbers to guide decisions and monitor policies.

In this present study, the authors focus on nine leading indicators characterizing different aspects of energy and environment policies. The Eurostat [33] and Odyssee-Mure databases 
[34] were used to estimate changes in GHG emissions in the energy production and other sectors. The indicators defined in the methodology, summarized in Table 1, constitute a set of sustainable development energy indicators helpful to policymakers, energy market analysts, and statisticians. Some indicators focus on energy efficiency, while others focus on the environmental impact.

Greenhouse gases per GDP have been chosen as a primary environmental policy-describing indicator. However, caution should be applied when assessed this indicator. A country with main economic activities related to banking and trade consumes less energy per unit of GDP than a country based on steel and ore processing.

The use of renewable energy technologies for power and heat generation has become increasingly popular in recent years. Some technologies have become cost-competitive with conventional energy generation, such as hydropower and biomass and wind and geothermal energy in suitable locations. However, in many cases, governmental aid policy remains the main driver of renewable energy technology implementation due to the high start-up costs. The state aid for renewable energy support has not been assessed in the context of this article due to the unavailability of data and incomparability.

TABLE 1. AN OVERVIEW OF USED INDICATORS

\begin{tabular}{|c|c|c|c|}
\hline Indicator & Unit & Input data & Source \\
\hline Greenhouse gases per GDP & $\mathrm{t}_{\mathrm{CO} 2 \mathrm{eq}} / \mathrm{MEUR}$ & $\begin{array}{l}\text { Greenhouse gases }{ }^{\dagger} \\
\text { Gross domestic product at market prices }\end{array}$ & {$[33]$} \\
\hline Share of RES & $\%$ & $\begin{array}{l}\text { Share of renewable energy in gross final energy } \\
\text { consumption }\end{array}$ & {$[33]$} \\
\hline Energy intensity & $\begin{array}{l}\text { TOE/ } \\
\text { MEUR }\end{array}$ & $\begin{array}{l}\text { Primary energy consumption } \\
\text { Gross domestic product at market prices }\end{array}$ & {$[33]$} \\
\hline Primary efficiency & $\%$ & $\begin{array}{l}\text { Primary energy consumption } \\
\text { Final energy consumption }\end{array}$ & {$[33]$} \\
\hline Industry efficiency & $\begin{array}{l}\text { TOE/ } \\
\text { MEUR }\end{array}$ & $\begin{array}{l}\text { Final energy consumption of industry sector } \\
\text { Value-added of industry }\end{array}$ & {$[33],[34]$} \\
\hline $\begin{array}{l}\text { Energy consumption in } \\
\text { households }\end{array}$ & $\begin{array}{l}\text { TOE per } \\
\text { inhabitant }\end{array}$ & $\begin{array}{l}\text { Final consumption in households } \\
\text { Population } \\
\text { Cooling/heating coefficient }\end{array}$ & {$[33]$} \\
\hline Space heating efficiency & $\begin{array}{l}\text { Index } \\
(2000=100)\end{array}$ & $\begin{array}{l}\text { Technical energy efficiency index of households } \\
\text { for space heating }\end{array}$ & {$[34]$} \\
\hline $\begin{array}{l}\text { Pollutant emissions from } \\
\text { transport }\end{array}$ & $\begin{array}{l}\text { Index } \\
(2000=100)\end{array}$ & Pollutant emissions from transport & {$[33]$} \\
\hline $\begin{array}{l}\text { Specific energy consumption } \\
\text { of transport sector }\end{array}$ & $\begin{array}{l}\text { TOE/ } \\
\text { MEUR }\end{array}$ & $\begin{array}{l}\text { Final energy consumption in transport sector } \\
\text { Gross domestic product at market prices }\end{array}$ & {$[33]$} \\
\hline
\end{tabular}

The energy intensity (EI) indicator results from the division of the gross available energy by GDP. It shows the productivity of energy consumption and gives an idea of the decoupling of energy consumption from GDP growth. Depending on the economy's structure, this indicator makes it possible to measure changes in energy efficiency, which may, in turn, be linked to changes in technology, energy mix, or consumer preferences or behaviour.

The primary efficiency indicator compares the primary energy consumption and the final energy consumption.

${ }^{\dagger} \mathrm{CO}_{2}, \mathrm{~N}_{2} \mathrm{O}, \mathrm{CH}_{4}, \mathrm{HFC}, \mathrm{PFC}, \mathrm{SF}_{6}, \mathrm{NF}_{3}$ expressed in $\mathrm{CO}_{2}$ equivalent 
The final energy consumption of the industry sector is divided by the value-added of the industry to evaluate and compare the efficiency of the industry efficiency.

Two different indicators are used to evaluate the energy policy and efficiency of households. Final energy consumption in households per inhabitant covers the overall energy consumption (space and water heating, water heating, cooling, cooking, electricity consumption, electrical appliances, etc.). In addition, the household efficiency of space heating as an index is compared for different EU27 countries by applying the climate condition normalization factor.

Emissions from transport are the main contributor to air pollution. Pollutant emissions from transport analyses the transport emissions of nitrogen oxides, non-methane volatile organic compounds, and particulate matter as an index to the year 2000.

The obtained indicator $j$ values for a particular country $i$ have been normalized using Weitendorf's linear normalization method [35]. Eq. (1) is used if the optimal indicator value needs to be maximized, and Eq. (2) is used if the desirable indicator value is minimal.

$$
\begin{gathered}
b_{i j}=\frac{x_{i j}-\min x_{i j}}{\max x_{i j}-\min x_{i j}} \\
b_{i j}=\frac{\max x_{i j}-x_{i j}}{\max x_{i j}-\min x_{i j}}
\end{gathered}
$$

The normalized values for the particular country are summed to determine ECPI for each country from which it is possible to obtain comprehensive insight into the energy and climate performance.

\section{Results}

The obtained results include the overall data analyses on GHG changes compared to GDP and population changes. Further, different indicators have been tested to obtain the relation between several impacting factors. Those indicators have been used to identify multidimensional indicators ECPI and evaluate the countries with the highest and lowest achievements in energy efficiency and environmental protection.

\subsection{Data analyses}

One of the indicators for sustainable development of the environment is GHG emissions from energy production per capita. Fig. 2 shows GHG emissions per capita in the EU from 2010 to 2017 . The average EU GHG emissions per capita in the energy sector decreased by $15 \%$ between 2010 and 2017 , down from $7.55 t_{\text {CO2eq }}$ to $6.59 t_{\text {CO2eq }}$ per capita in 2017 . In 2017 , Luxembourg had the highest GHG emissions among EU countries. Latvia has the lowest GHG emissions per capita in 2010 with $3.98 \mathrm{t}_{\mathrm{CO} 2 \mathrm{eq}} /$ capita, but in 2017 the lowest value is for Malta with $3.51 \mathrm{t}_{\mathrm{CO} 2 \mathrm{eq}} /$ capita, which has seen a $75 \%$ reduction in per capita GHG emissions over this period. 


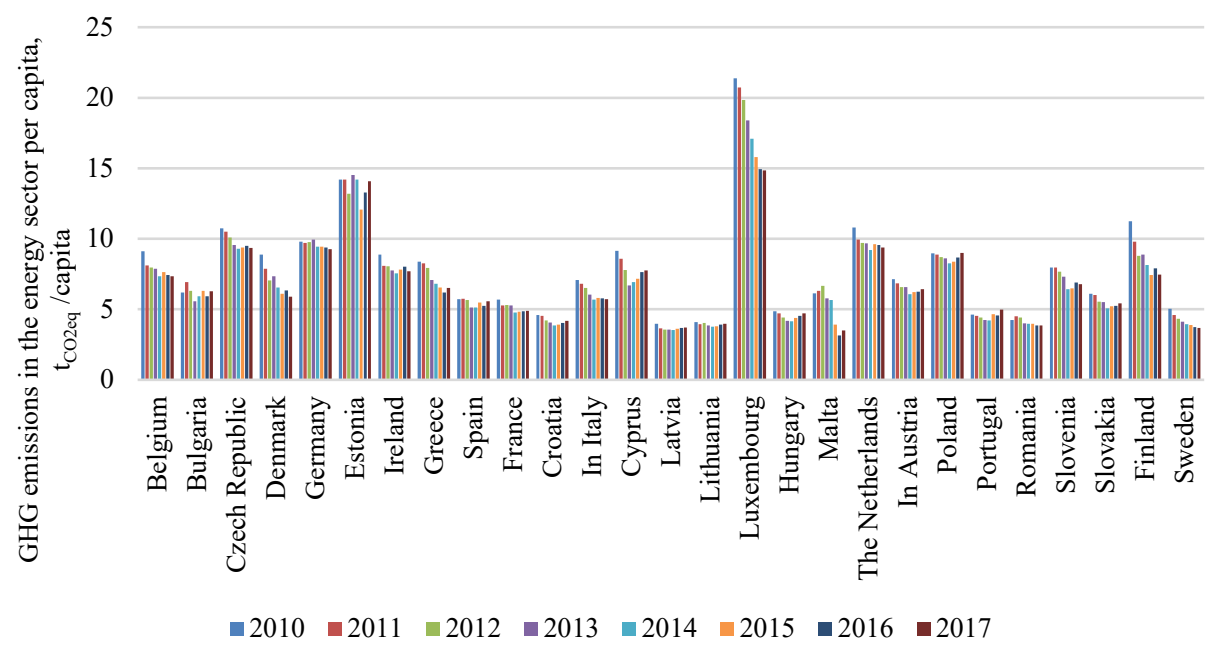

Fig. 2. GHG emissions per capita in EU countries, 2010-2017.

Per capita GHG emissions in the energy sector should be analysed in the context of population change. Fig. 3 shows the relative changes in GHG emissions in each EU country relative to population changes over eight years.

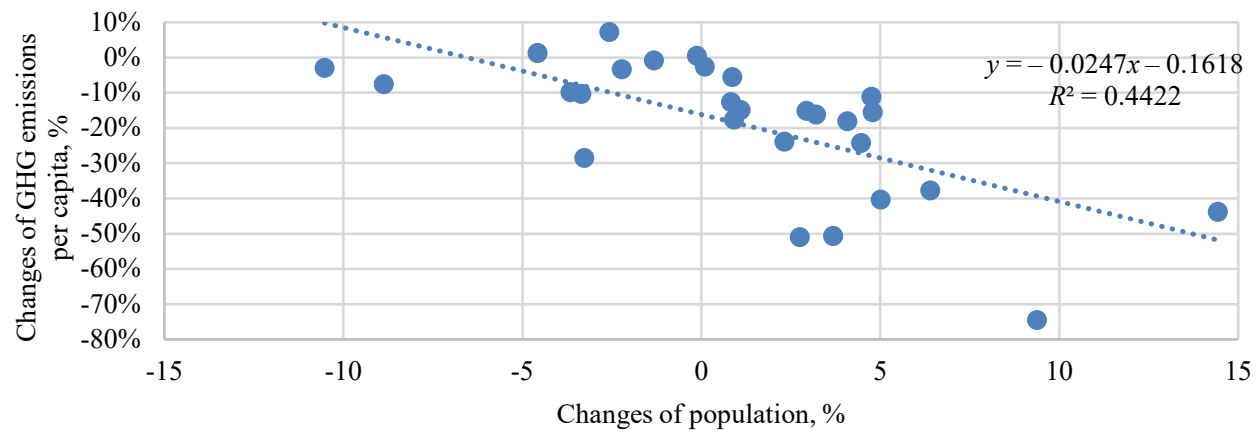

Fig. 3. Changes in GHG emissions in the energy sector relative to population changes.

Fig. 3 shows that most countries are reducing their GHG emissions per capita despite population changes, even if the regression coefficient is low. It indicates that the growing population is not proportionally producing more GHG emissions to meet its energy needs. A benchmark can be created to show which countries have higher GHG emission reductions relative to population change and which countries have less impact on the overall GHG emissions.

The second indicator under consideration is GHG emissions in the energy sector divided by GDP. The comparison for different EU countries can be seen in Fig. 4. The EU average specific GHG emissions in the energy sector fell by $1 \%$ from 295.7 t $_{\text {CO2eq }} /$ MEUR in 2010 to $218.54 t_{\mathrm{CO} 2 \mathrm{eq}}$ /MEUR between 2010 and 2017. The highest value of the indicator in 2010 was for Estonia, which reached $1274.31 \mathrm{t}_{\mathrm{CO} 2 \mathrm{eq}} / \mathrm{MEUR}$, while the lowest indicator value was for 
Sweden - 125.9 $\mathrm{t}_{\mathrm{CO} \text { eq }}$ /M EUR. In 2017, Bulgaria had the highest value of 852.8, but the lowest value remains for Sweden - $76.4 \mathrm{t}_{\mathrm{CO} 2 \mathrm{eq}}$ /MEUR. The most significant decrease in the absolute value of the indicator is observed in Estonia from $1274.3 \mathrm{t}_{\mathrm{CO} 2 \mathrm{eq}} / \mathrm{MEUR}$ to $779.5 \mathrm{t}_{\mathrm{CO} 2 \mathrm{eq}} / \mathrm{MEUR}$. Malta has the most significant overall percentage reduction, showing the total reduction in GHG emissions to GDP by $169 \%$, while Portugal has the slightest reduction in both absolute and percentage terms $(4 \%)$.

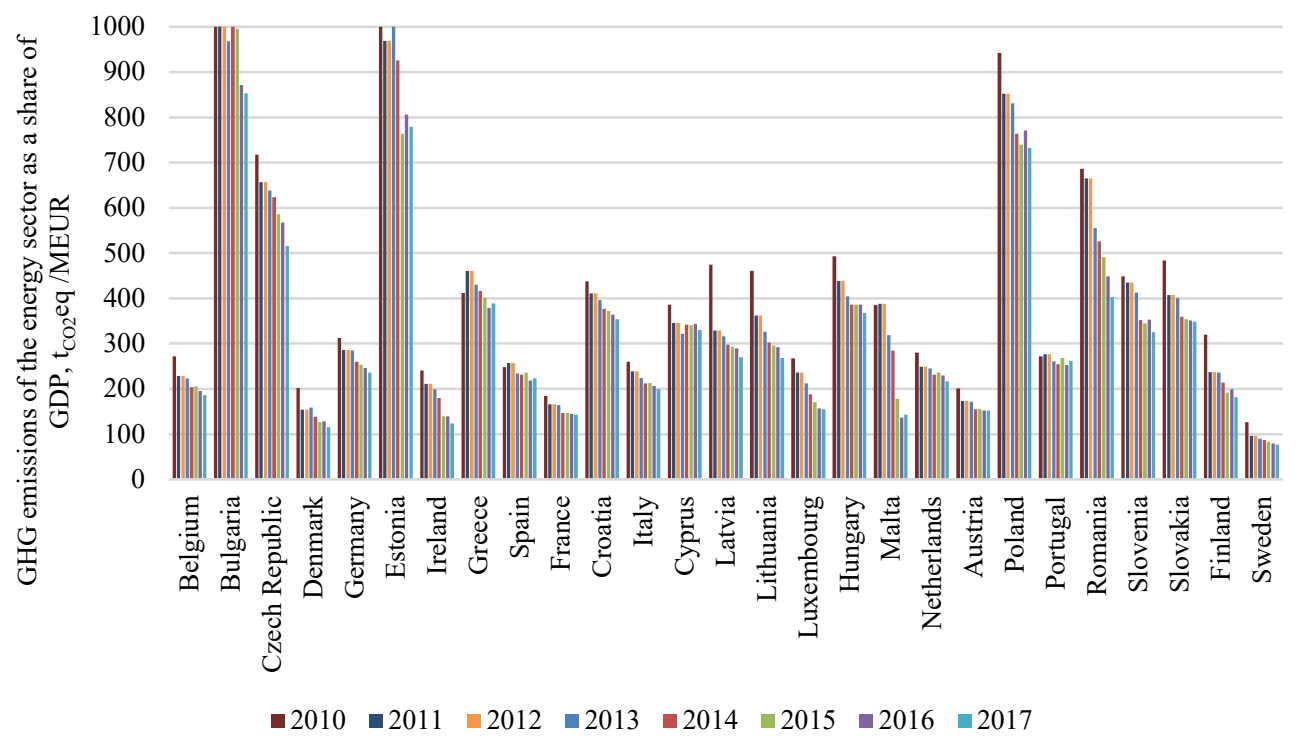

Fig. 4. GHG emissions in the energy sector as a share of GDP.

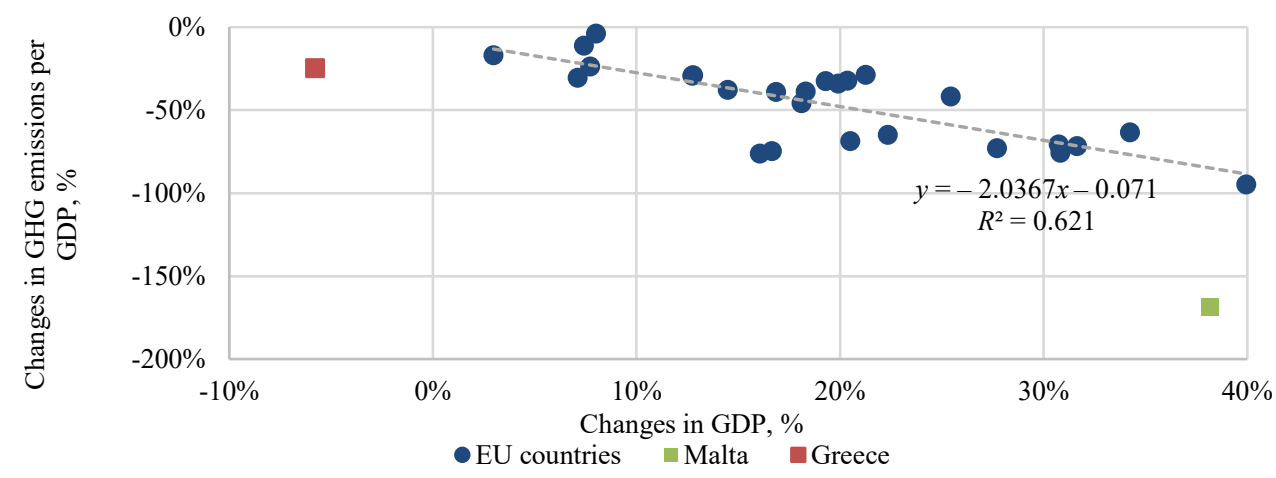

Fig. 5. Changes in specific GHG emissions versus changes in GDP.

Fig. 5 shows the change in the ratio of GHG emissions versus changes in GDP. The GDP of EU countries except for Greece has increased between 2010 and 2017. Changes in the ratio of GHG emissions to GDP have decreased in all EU countries, which means that increasing national GDP does not increase GHG emissions proportionally. The greater the GDP growth, the greater the value of the indicator. The sharp emission drop in Malta in 2015 (169\%) was mainly due to the switch to more efficient turbines for electricity generation and the use of 
the electricity interconnector linking Malta with Sicily's electricity grid [36]. The obtained regression equation in Fig. 5 can serve as a simplified benchmark for evaluating climate policy efficiency.

\subsection{Indicator testing}

Through correlation analyses, indicators have been tested to evaluate the main driving factors for the GHG emission reduction. Fig. 6 shows the indicator values for different countries in the period from 2010 to 2017. There is a strong correlation between GDP per capita and GHG emissions per GDP (see Fig. 6a). An increase in GDP results in a decrease in specific GHG emissions, which could be due to energy efficiency increase and integration of RES technologies. Nevertheless, for Luxembourg and Estonia, the specific amount of emissions is higher when comparing to other countries.

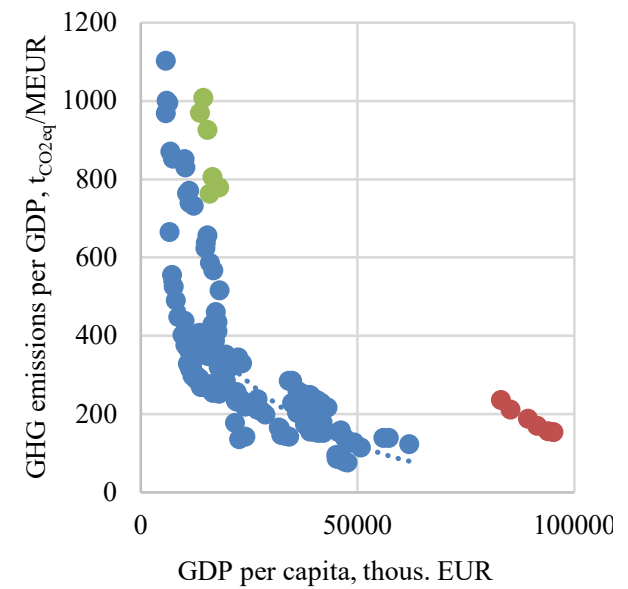

- Luxembourg

a)

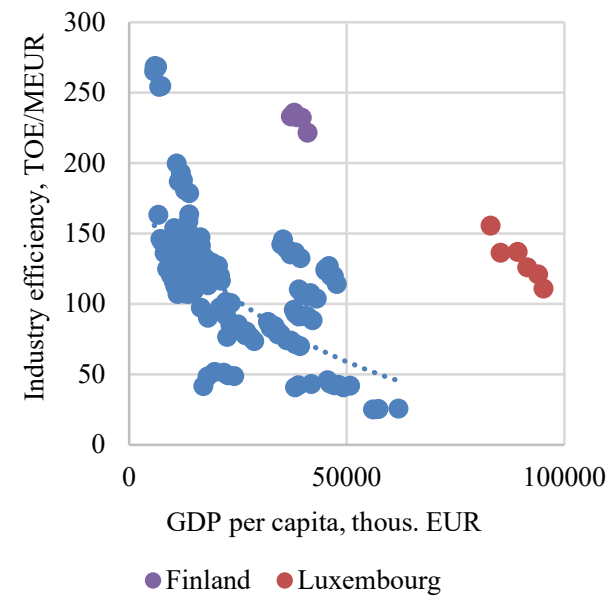

c)

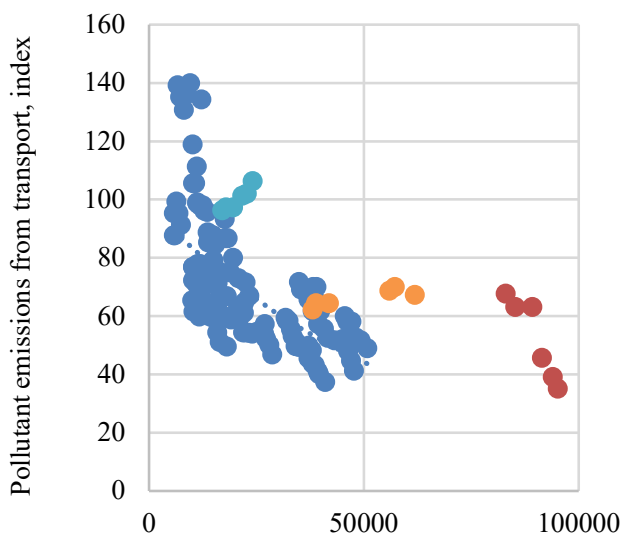

GDP per capita, thous. EUR

Ireland Malta Luxembourg

b)

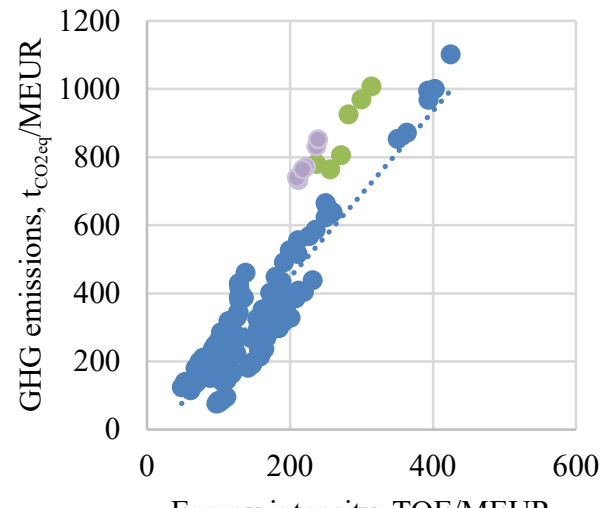

Energy intensity, TOE/MEUR Estonia Poland

d)

Fig. 6. Results of correlation analyses for indicator testing. 
$2021 / 25$

GDP per capita has been identified as a driving force for the decrease of pollutant emissions from transport. Countries with pollutant emissions from transport higher than other EU countries are Malta, Ireland, and Luxembourg. Industry efficiency indicator shows the correlation with the GDP per capita. Exceptions are Luxembourg and Finland, where most of GDP is generated by the service sector. It can be seen in Fig. 6d that the energy intensity indicator (primary energy consumption per GDP) has a strong correlation with the specific GHG emissions. Higher values are obtained for Poland and Estonia, where the leading role in the energy balance is dedicated to energy sources with high primary energy factors (coal and oil shale).

\subsection{Grouping of countries}

To evaluate the overall environmental and energy performance in different EU countries, authors had determined 9 different indicators in 2017. Those values are further normalized to be comparable among the countries. In Table 2, the highest value of the particular indicator is rated as 1 , but the lowest indicator value is 0 .

TABLE 2. OVERVIEW OF INDICATOR VALUES FOR DIFFERENT EU 27 COUNTRIES IN 2017

\begin{tabular}{lccccccccc}
\hline Country & RES & GHG/GDP & EI & $\mathbf{E C}_{\text {resid }}$ & $\mathbf{N O}_{\text {tran }}$ & $\boldsymbol{\eta}_{\text {primary }}$ & $\mathbf{E E}_{\text {IND }}$ & $\mathbf{E E}_{\text {resid }}$ & $\mathbf{E C}_{\text {tran }}$ \\
\hline Austria & 0.5 & 0.9 & 0.9 & 0.4 & 0.8 & 0.9 & 0.7 & 0.8 & 0.9 \\
\hline Belgium & 0.1 & 0.9 & 0.8 & 0.2 & 0.8 & 0.6 & 0.5 & 0.6 & 0.9 \\
\hline Bulgaria & 0.3 & 0 & 0 & 0.9 & 0.5 & 0.1 & 0 & 0.4 & 0.7 \\
\hline Croatia & 0.4 & 0.6 & 0.6 & 0.4 & 0.6 & 0.8 & 0.6 & 0.4 & 0.9 \\
\hline Cyprus & 0.1 & 0.7 & 0.7 & 0.1 & 0.7 & 0.6 & 0.7 & 0.2 & 1 \\
\hline Denmark & 0.6 & 0.9 & 1 & 0.3 & 0.9 & 0.8 & 0.9 & 0.6 & 1 \\
\hline Estonia & 0.5 & 0.1 & 0.4 & 0.7 & 0.9 & 0 & 0.7 & 0.7 & 1 \\
\hline Finland & 0.7 & 0.9 & 0.7 & 0.6 & 1 & 0.8 & 0.1 & 0.8 & 0.9 \\
\hline France & 0.2 & 0.9 & 0.8 & 0.3 & 0.8 & 0.4 & 0.8 & 0.4 & 0.2 \\
\hline Germany & 0.2 & 0.8 & 0.9 & 0.4 & 0.9 & 0.6 & 0.8 & 0.7 & 0.2 \\
\hline Greece & 0.2 & 0.6 & 0.7 & 0.5 & 0.6 & 0.6 & 0.5 & 0.3 & 0.8 \\
\hline Hungary & 0.1 & 0.6 & 0.5 & 0.4 & 0.8 & 0.7 & 0.5 & 0.3 & 0.8 \\
\hline Ireland & 0.1 & 0.9 & 1 & 0.5 & 0.7 & 0.8 & 1 & 0.7 & 1 \\
\hline Italy & 0.2 & 0.8 & 0.9 & 0.3 & 0.9 & 0.7 & 0.8 & 0 & 0.3 \\
\hline Latvia & 0.7 & 0.8 & 0.6 & 0.7 & 0.7 & 0.9 & 0.4 & 0.9 & 1 \\
\hline Lithuania & 0.4 & 0.8 & 0.7 & 0.8 & 0.5 & 0.9 & 0.6 & 0.6 & 0.9 \\
\hline Luxembourg & 0 & 0.9 & 0.9 & 0 & 1 & 1 & 0.6 & 0.6 & 0 \\
\hline Malta & 0 & 0.9 & 0.9 & 0.7 & 0.3 & 0.7 & 0.9 & 0.6 & 1 \\
\hline Netherlands & 0 & 0.8 & 0.9 & 0.4 & 0.8 & 0.7 & 0.7 & 0.6 & 0.9 \\
\hline Poland & 0.1 & 0.2 & 0.5 & 0.7 & 0.1 & 0.6 & 0.6 & 0.6 & 0 \\
\hline Portugal & 0.5 & 0.8 & 0.8 & 0.5 & 0.8 & 0.6 & 0.5 & 0.1 & 0.8 \\
\hline Romania & 0.4 & 0.6 & 0.6 & 0.9 & 0 & 0.6 & 0.6 & 0.8 & 0.6 \\
\hline Slovakia & 0.1 & 0.6 & 0.5 & 0.9 & 0.6 & 0.5 & 0.5 & 0.8 & 0.9 \\
\hline Slovenia & 0.3 & 0.7 & 0.6 & 0.6 & 0.6 & 0.6 & 0.6 & 0.5 & 1 \\
\hline Spain & 0.2 & 0.8 & 0.8 & 1 & 0.8 & 0.5 & 0.8 & 0.3 & 0.3 \\
\hline Sweden & 1 & 1 & 0.8 & 0.8 & 0.9 & 0.6 & 0.7 & 1 & 0.9 \\
\hline The Czech Republic & 0.2 & 0.4 & 0.5 & 0.5 & 0.7 & 0.4 & 0.6 & 0.6 & 0.8 \\
\hline
\end{tabular}

As shown in Table 2, the indicator score is complex. For several countries, there are both very high and low values of different indicators. For example, Belgium has a very low share 
of RES in the total energy balance (rated as 0.1) and high specific energy consumption of the residential sector (rated as 0.2). However, the specific GHG emissions (GHG/GDP) and energy intensity (EI) is at reasonable rate and the indicators of the transport sector are high. The analyses show the main bottlenecks for each country and can indicate the possible areas to focus the policy instruments.

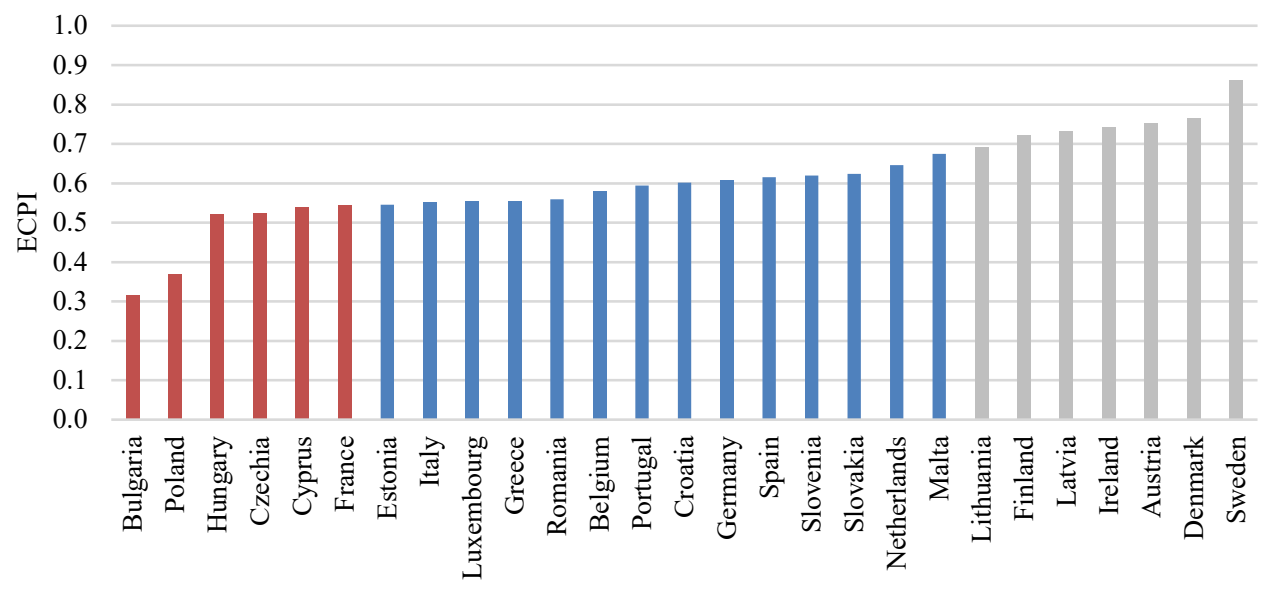

Fig. 7. ECPI values for different countries in 2017.

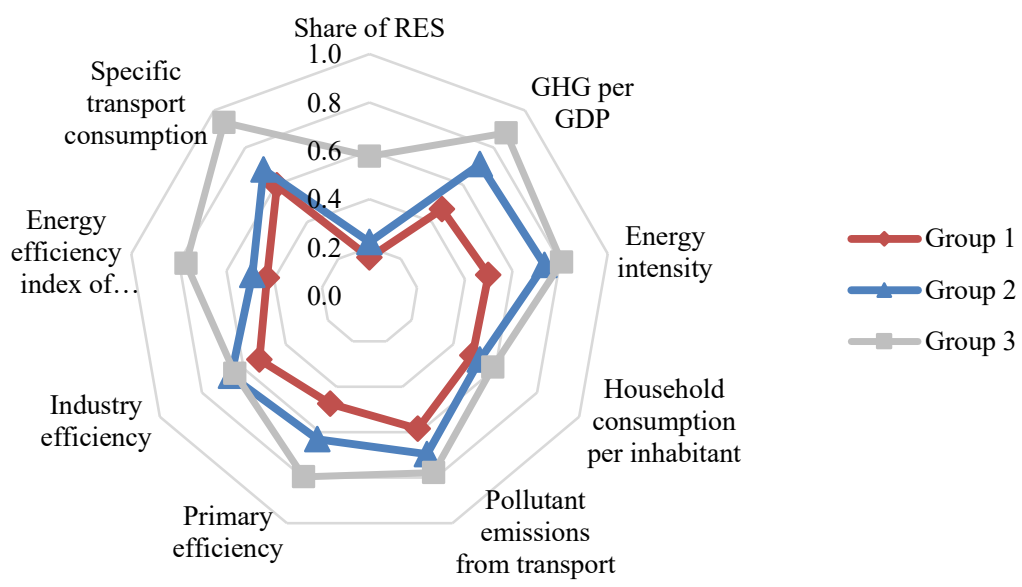

Fig. 8. The summed rating of different indicators.

The normalized values of indicators are summed and ranked. Fig. 7 shows the ranking of the 27 EU countries and the division in three different groups related to overall climate and energy performance status. According to statistical analyses dividing obtained results in quartiles, countries with a score below 0.55 are in Group 1 , but countries with a score above 0.67 are in Group 3, showing the highest indicator values. Group 2 consolidates the countries 
with average indicator values. The boundaries are not definite. Countries with an average rating can join Group 1 or Group 3 by adding or subtracting one of the rating indicators. However, the number of indicators has a minor impact on the overall rating of the countries with the highest (Sweden, Denmark) and lowest values (Bulgaria, Poland).

Fig. 8 shows the average rating for different indicators in each group. As can be seen, there are indicators with the significant differences among different groups (specific transport consumption, share of RES, Energy intensity and GHG emissions per GDP, primary efficiency). However, the industry efficiency and the specific household consumption values are not so different for countries in Group 1, 2, and 3.

\section{CONCLUSION AND POLICY IMPLiCATIONS}

The article presents the methodology for climate and energy performance analyses by applying different indicators and identifying multidimensional ECPI index. The methodology allows evaluating and comparing the existing situation related to GHG emissions and energy efficiency in different sectors.

The article includes the overall data analyses of GHG emissions per capita and GDP value to evaluate the existing situation in EU27 countries in the period of 2010-2017. The data analyses show that the increase in GDP since 2010 has not increased GHG emissions.

Authors have identified nine different indicators for energy and environmental performance analyses in different sectors: share of renewable energy, greenhouse gases per GDP, energy intensity, primary efficiency, industry efficiency, energy consumption in households, space heating efficiency, pollutant emissions from transport, and specific energy consumption of transport sector.

The particular indicators have been evaluated through correlation analyses to determine the relationship between energy efficiency and environmental aspects. Authors conclude that there is a strong relation between specific GHG emissions, pollutant emissions from transport, industry efficiency, and GDP per capita. The countries' specific energy intensity has also impacted the specific GHG emissions. Such correlation analyses allow identifying few countries, which do not respond to the overall tendency in EU. For example, Malta, and Ireland have higher pollutant emissions from transport when comparing it with other countries with similar GDP per capita values.

The normalization and ranking of obtained ECPI index values resulted in the grouping of EU countries according to their performance. Group 1 merge those EU member states with the lowest ECPI, Bulgaria, Poland, Hungary, the Czech Republic, Cyprus and France. Group 3 includes the countries with the best rating - Sweden, Denmark, Austria, Ireland, Latvia, Finland and Lithuania. In Group 2, all other countries with average ratings have been included.

The developed methodology and grouping of EU countries could serve as a base for forecasting models. The identified indicators can be used for further evaluation of climate and energy policies in different EU countries.

\section{ACKNOWLEDGMENTS}

This research is funded by the Ministry of Economics of the Republic of Latvia, project 'Energy and climate modelling towards net zero emissions', project No. VPP-EM-2018/NEKP-0001. 


\section{REFERENCES}

[1] Dudin M. N., Frolova E. E., Protopopova O. V., Mamedov A., Odintsov S. V. Study of innovative technologies in the energy industry: Nontraditional and renewable energy sources. Enterpreneurship and Sustainibility Issues 2019:6(4):1704-1713. https://doi.org/10.9770/jesi.2019.6.4(11)

[2] European Commission. Directive 2009/28/EC of the European Parliament on the promotion of the use of energy from renewable sources and amending and subsequently repealing Directives 2001/77/EC and 2003/30/EC. Eur. Wind Energy Conf. Exhib. 2008:1:32-38.

[3] European Commission. Directive (EU) 2018/2001 of the European Parliament and of the Council on the promotion of the use of energy from renewable sources. Official Journal of European Union 2018: L 328.

[4] European Commission. A Clean Planet for all. A European strategic long-term vision. 2018. [Online]. [Accessed: 19.03.2021]. Available: https://eur-lex.europa.eu/legal-content/EN/TXT/PDF/?uri=CELEX:52018DC0773\&from= EN

[5] Lowe S. The EU's carbon border adjustment mechanism How to make it work for developing countries. 2021. [Online]. [Accessed: 14.06.2021]. Available: https://www.cer.eu/sites/default/files/pbrief_cbam_sl_21.4.21.pdf

[6] Cifci E., Oliver M. E. Reassessing the links between GHG emissions, economic growth, and the UNFCCC: A difference-in-differences approach. Sustainability 2018:10(2):334. https://doi.org/10.3390/su10020334

[7] Papież M., Śmiech S., Frodyma K. Effects of renewable energy sector development on electricity consumption Growth nexus in the European Union. Renewable and Sustainable Energy Reviews 2019:113:109276. https://doi.org/10.1016/j.rser.2019.109276

[8] Fraune C., Knodt M. Sustainable energy transformations in an age of populism, post-truth politics, and local resistance. Energy Research \& Social Science 2018:43:1-7. https://doi.org/10.1016/j.erss.2018.05.029

[9] Ntanos S., Skordoulis M., Kyriakopoulos G., Arabatzis G., Chalikias M., Galatsidas, S., Batzios A., Katsarou A. Renewable Energy and Economic Growth: Evidence from European Countries. Sustainability 2018:10(8):10082626. https://doi.org/10.3390/su10082626

[10] Simionescu M., Yuriy B., Gedek S., Streimikiene D. The Effects of Greenhouse Gas Emissions on Cereal Production in the European Union. Sustainability 2019:11(12):3433. https://doi.org/10.3390/su11123433

[11] Gielen D., Boshell F., Saygin D., Bazilian M. D., Wagner N., Gorini R. The role of renewable energy in the global energy transformation. Energy Strategy Reviews 2019:24:38-50. https://doi.org/10.1016/j.esr.2019.01.006

[12] Marinaș M.-C., Dinu M., Socol A.-G., Socol C. Renewable energy consumption and economic growth. Causality relationship in Central and Eastern European countries. PLoS One 2018:13(10):e0202951. https://doi.org/10.1371/journal.pone.0202951

[13] Saad W., Taleb A. The causal relationship between renewable energy consumption and economic growth: evidence from Europe. Clean Technology and Environmental Policy 2018:20(1):127-136. https://doi.org/10.1007/s10098017-1463-5

[14] Tavakoli A. A journey among top ten emitter country, decomposition of 'Kaya Identity'. Sustainable Cities and Society 2018:38:254-264. https://doi.org/10.1016/j.scs.2017.12.040

[15] Liobikienė G., Butkus M. The European Union possibilities to achieve targets of Europe 2020 and Paris agreement climate policy. Renewable Energy 2017:106:298-309. https://doi.org/10.1016/j.renene.2017.01.036

[16] International Atomic Energy Agency. Energy indicators for sustainable development: guidelines and methodologies. 2007. [Online]. [Accessed: 10.06.2021]. Available: http://wwwpub.iaea.org/MTCD/publications/PDF/Pub1222_we b.pdf

[17] Papież M., Śmiech S., Frodyma K. Determinants of renewable energy development in the EU countries. A 20-year perspective. Renewable and Sustainable Energy Reviews 2018:91:918-934. https://doi.org/10.1016/j.rser.2018.04.075

[18] Liobikienè G., Butkus M. The challenges and opportunities of climate change policy under different stages of economic development. Science of the Total Environment 2018:642:999-1007. https://doi.org/10.1016/j.scitotenv.2018.06.140

[19] Liobikienė G., Butkus M. Scale, composition, and technique effects through which the economic growth, foreign direct investment, urbanization, and trade affect greenhouse gas emissions. Renewable Energy 2019:132:1310-1322. https://doi.org/10.1016/j.renene.2018.09.032

[20] Rugani B., Marvuglia A., Pulselli F. M. Predicting Sustainable Economic Welfare - Analysis and perspectives for Luxembourg based on energy policy scenarios. Technological Forecasting and Social Change 2018:137:288-303. https://doi.org/10.1016/j.techfore.2018.08.005

[21] Siksnelyte I., Zavadskas E. K., Bausys R., Streimikiene D. Implementation of EU energy policy priorities in the Baltic Sea Region countries: Sustainability assessment based on neutrosophic MULTIMOORA method. Energy Policy 2019:125:90-102. https://doi.org/10.1016/j.enpol.2018.10.013

[22] Lyeonov S., Pimonenko T., Bilan Y., Štreimikienė D., Mentel G. Assessment of Green Investments' Impact on Sustainable Development: Linking Gross Domestic Product Per Capita, Greenhouse Gas Emissions and Renewable Energy. Energies 2019:12(20):12203891. https://doi.org/10.3390/en12203891 
[23] Cohen G., Jalles J. T., Loungani P., Marto R., Wang G. Decoupling of emissions and GDP: Evidence from aggregate and provincial Chinese data. Energy Economics 2019:77:105-118. https://doi.org/10.1016/j.eneco.2018.03.030

[24] Vasylieva T., Lyulyov O., Bilan Y., Streimikiene D. Sustainable economic development and greenhouse gas emissions: The dynamic impact of renewable energy consumption, GDP, and corruption. Energies 2019:12(17):3289. https://doi.org/10.3390/en12173289

[25] Sánchez D. R., Hoadley A. F. A., Khalilpour K. R. A multi-objective extended input-output model for a regional economy. Sustainable Production and Consumption 2019:20:15-28. https://doi.org/10.1016/j.spc.2019.04.009

[26] Baležentis T., Streimikiene D., Zhang T., Liobikiene G. The role of bioenergy in greenhouse gas emission reduction in EU countries: An Environmental Kuznets Curve modelling. Resources Conservation and Recycling 2019:142:225-231. https://doi.org/10.1016/i.resconrec.2018.12.019

[27] Cucchiella F., D’Adamo I., Gastaldi M., Miliacca M. Efficiency and allocation of emission allowances and energy consumption over more sustainable European economies. Journal of Cleaner Production 2018:182:805-817. https://doi.org/10.1016/j.jclepro.2018.02.079

[28] Alola A. A., Bekun F. V., Sarkodie S. A. Dynamic impact of trade policy, economic growth, fertility rate, renewable and non-renewable energy consumption on ecological footprint in Europe. Science of the Total Environment 2019:685:702-709. https://doi.org/10.1016/j.scitotenv.2019.05.139

[29] Zheng X., Streimikiene D., Balezentis T., Mardani A., Cavallaro F., Liao H. A review of greenhouse gas emission profiles, dynamics, and climate change mitigation efforts across the key climate change players. Journal of Cleaner Production 2019:234:1113-1133. https://doi.org/10.1016/j.jclepro.2019.06.140

[30] Nong D., Siriwardana M. Effects on the U.S. economy of its proposed withdrawal from the Paris Agreement: A quantitative assessment. Energy 2018:159:621-629. https://doi.org/10.1016/j.energy.2018.06.178

[31] Saqib N. Greenhouse gas emissions, energy consumption and economic growth: Empirical evidence from gulf cooperation council countries. International Journal of Energy Economics and Policy 2018:8(6):392-400. https://doi.org/10.32479/ijeep.7269

[32] Rajbhandari S., Limmeechokchai B., Masui T. The impact of different GHG reduction scenarios on the economy and social welfare of Thailand using a computable general equilibrium (CGE) model. Energy, Sustainability and Society 2019:9(1). https://doi.org/10.1186/s13705-019-0200-9

[33] Eurostat database, No Title, 2020. [Online]. [Accessed: 12.04.2021]. Available: https://ec.europa.eu/eurostat/cache/metadata/en/env_air_gge_esms.htm

[34] EnerData, Odyssee-Mure database, 2020. [Online]. [Accessed: 12.04.2021]. Available: https://odyssee.enerdata.net/home/

[35] Turskis Z., Zavadskas E. K., Peldschus F. Multi-criteria optimization system for decision making in construction design and management. Eng. Econ. 2009:1(61):7-17.

[36] Malta Resources Authority, Third Biennial Report, 2018. [Online]. [Accessed: 12.04.2021]. Available: https://www4.unfccc.int/sites/SubmissionsStaging/NationalReports/Documents/92604815_Malta-BR3-1BR3_Malta_final.pdf 